\title{
Analisis Keterampilan Metakognisi Siswa Pada Mata Pelajaran IPA Biologi di SMP Kota Ternate
}

\author{
Ermin* \\ STKIP Kie Raha Ternate, Ternate, Indonesia \\ *Coresponding Author: mincesermin@gmail.com \\ Dikirim: 06-06-2021 ; Direvisi: 07-06-2021 ; Diterima: 07-06-2021
}

\begin{abstract}
Abstrak: Tujuan dari penelitian ini untuk mengetahui keterampilan metakognisi siswa pada mata pelajaran IPA Biologi SMP di Kota Ternate. Metode yang digunakan dalam penelitian menggunkan pendekatan diskriptif kuantitatif. Teknik pengumpulan sampel yaitu dengan menggunakan cara random, penentuan sampel dilakukan secara strata berdasarkan wilayah, yang terdiri dari SMP Negeri 4 wilayah kota dan SMP Negeri 11 wilayah pulau Ternate, denga jumlah sampel sebanyak 40 siswa yang terdiri dari 20 siswa SMP Negeri 4 dan 20 siswa SMP Negeri 11pulau Ternate. Data yang dikumpulkan berupa hasil tes, dengan jumlah sebanyak 5 soal dan bentuk soal esaay yang disusun berdasarkan tiga indikator peneilaian keterampilan metakognisi. Berdasrkan hasil penelitian diperoleh nilai rata-rata keterampilan metakognisi siswa kelas VII SMP 4 Kota Ternate sebesar 57,18 dan SMP Negeri 11 pulau Ternate sebesar 48,63 dengan selisih perolehan 8,55 namun kedua sekolah masuk pada kategori Development, dapat dikatakan bahwa keterampilan metakognisi siswa masih rendah. Renadahnya keterampilan metakognisi siswa diduga karena guru belum memberdayakan keterampilan metakognisi dengan baik. Pendekatan pembelajaran yang digunakan guru masih bersifat konvensional.
\end{abstract}

Kata Kunci: Keterampilan metakognisi, Pelajaran IPA Biologi SMP

Abstract: The purpose of this study was to determine the metacognitive skills of students in the Biology Science subject of Junior High School in Ternate City. The method used in the study uses a quantitative descriptive approach. The sample collection technique is by using a random method, the determination of the sample is carried out strata based on the region, which consists of SMP Negeri 4 in the city area and SMP Negeri 11 in the Ternate island region, with a sample of 40 students consisting of 20 students from SMP Negeri 4 and 20 students. SMP Negeri 11 Ternate Island. The data collected is in the form of test results, with a total of 5 questions and the form of essay questions which are arranged based on three indicators for assessing metacognition skills. Based on the results of the study, the average value of the metacognitive skills of grade VII students of SMP 4 Ternate City was 57.18 and SMP Negeri 11 Ternate Island was 48.63 with a difference of 8.55 but both schools were included in the Development category, it can be said that metacognition skills students is still low. The low level of students' metacognitive skills is thought to be because the teacher has not empowered metacognitive skills properly. The learning approach used by the teacher is still conventional.

Keywords: Metacognition Skills, Junior High School Biology Science Lessons

\section{PENDAHULUAN}

Pembelajaran biologi di SMP menerapkan prinsip-prinsip pembelajaran IPA. Prinsip-prinsip tersebut sebagai berikut: 1) Ilmu Pengetahuan Alam (IPA) berkaitan dengan cara mencari tahu (inquiry) tentang alam, 2) IPA bukan hanya kumpulan pengetahuan fakta, konsep atau prinsip saja, tetapi juga merupakan suatu proses penemuan, 3) IPA menjadi wahana bagi peserta didik untuk mempelajari diri sendiri 
dan alam sekitar, 4) IPA menekankan pada pemberian pengalaman langsung untuk mengembangkan kompetensi, dan 5) Biologi sebagai salah satu bidang IPA menyediakan berbagai pengalaman belajar untuk memahami konsep dan proses sains. Keterampilan proses ini meliputi keterampilan mengamati, mengajukan hipotesis, menggunakan alat dan bahan secara baik dan benar dengan selalu mempertimbangkan keamanan dan keselamatan kerja, mengajukan pertanyaan, menggolongkan dan menafsirkan data, serta mengkomunikasikan hasil temuan secara lisan atau tertulis, menggali dan memilah informasi faktual yang relevan untuk menguji gagasan-gagasan atau memecahkan masalah sehari-hari, dan mata pelajaran biologi dikembangkan melalui kemampuan berpikir analitis, induktif, dan deduktif untuk menyelesaikan masalah yang berkaitan dengan peristiwa alam sekitar, (Peraturan Menteri Pendidikan Nasional RI No 22 Tahun 2006).

Mengacu kepada prinsip-prinsip yang dipaparkan pada Permendiknas tentang standar isi pembelajaran biologi di SMP di atas, dapat di dadasari pada beberapa hal penting yang perlu dipahami dan dijadikan sebagai landasan bagi para guru biologi dalam mengembangkan pembelajaran biologi yaitu: 1) biologi merupakan bagian dari IPA yang tidak terlepas dari proses penemuan atau penyelidikan (inquary) tentang alam secara ilmiah, 2) membekali peserta didik untuk mengembangkan kemampuan berpikir kritis (analitik, induktif, deduktif, merumuskan hipotesis) dan memecahkan masalah alam sekitar, 3) melatih siswa mempelajari dan mengenali diri sendiri secara lebih mendalam, dan 4) membantu siswa mengembangkan kompetensi, pemahaman konsep dan keterampilan.

Keterampilan metakognisi merupakan kemampuan siswa dalam mengelola sendiri aktivitas belajar (Self regulation), dan kemampuan siswa dalam mengelola sendiri pengetahuan dan kemampuanya dalam belajar (self evaluation). Keterampilan metakognisi dianggap memainkan peranan penting dalam banyak jenis aktivitas kognitif termasuk pemahaman. Selain itu pemberdayaan ketrampilan metakognisi siswa perlu dilakukan. Hal ini sejalan dengan pendapat Corebima (2009), pemberdayaan keterampilan metakognisi perlu dilakukan agar siswa menjadi pebelajar yang mandiri.

Keterampilan metakognisi dapat memainkan peranan penting dalam banyak aktivitas kognitif termasuk pemahaman. Proses keterampilan metakognisi dapat membantu siswa menjadi mandiri dan dapat memberikan pengaruh terhadap peningkatan hasil belajar (Bahri and Corebima,2015). Hacker (2009) menyatakan bahwa metakognisi memungkinkan sesorang untuk bertanggung jawab atas pembelajaran mereka sendiri. Ini dapat melibatkan kesadaran bagaimana mereka belajar, evaluasi kebutuhan belajar mereka, menghasilakan strategi untuk memenuhi kebutuhan tersebut dan kemudian menerapkan strategi. Metakonisi melibatkan pengetahuan tinggi yang melibatkan kontrol aktif dari proses kognitif dalam belajar.

Keterampilam metakognisi dapat dilatihkan melalui pembelajaran konstruktivisme. Menurut Peters (2006), terdapat hubungan yang erat antara metakognisi dengan pembelajaran konstruktivistik. Pemberdayaan keterampilan metakognisi siswa dapat dilakukan, karena pembelajaran konstruktivistik menunutut siswa menemukan dan mengkonstruksian sendiri pengetahuan. Menurut Vijayaratman (2009) untuk mengembangkam keterampilam berpikir yang efektif pengajar harus memberikan perhatian khusus pada siswa dan untuk menjadikan 
siswa berpikir. Tujuan dari penelitian ini untuk mengetahui keterampilan metakognisi siswa pada mata pelajaran IPA Biologi SMP di Kota Ternate.

\section{METODE PENELITIAN}

Metode yang digunakan dalam penelitian ini yaitu pendekatan diskriptif kuantitatif. Menurut Sugiono, (2006) pendekatan deskriptif kuantitatif merupakan penyajian data dari hasil analisis kuantitatif kemudian dideskripakan dalam bentuk deskriptif. Data yang sajikan adalah data nilai rata-rata keterampilan metakognisi siswa secara kuantitatif dan dinarasikan dalam bentukan sajian deskriptif. Teknik pengumpulan sampel yaitu dengan menggunakan cara random, penentuan sampel dilakukan secara strata berdasarkan wilayah, yang terdiri dari SMP Negeri 4 wilayah kota dan SMP Negeri 11 wilayah pulau Ternate, denga jumlah sampel sebanyak 40 yang terdiri dari 20 siswa SMP N 4 dan 20 siswa SMP N 11. Data yang dikumpulkan berupa hasil tes, dengan jumlah sebanyak 5 soal dan bentuk soal esaay yang disusun berdasarkan indikator peneilaian keterampilan metakognisi (Schoenfeld, 1992). Keterampilan metakognis diukur dengan menggunakan rubrik yang mengacu pada Corebima (2009) dengan skala 0-7. Pengkategorian keterampilan metakognisi menggunakan Rating Scale yang diadaptasi dari Green (2002), yang terdiri atas kategori Super dengan skor 96-120, OK dengan skor 72-95, kategori Developmnet dengan skor 48-71, kategori At Risk skor 24-47, dan Not Yet dengan skor 0-24.

\section{HASIL DAN PEMBAHASAN}

\section{Hasil Rata-Rata Keterampilan Metakognisi Siswa Kelas VII SMP di Kota Ternate}

Tabel 1. Rata-rata Nilai Keterampilan Metakognisi Siswa SMP di Kota Ternate

\begin{tabular}{cccc}
\hline No & Sekolah & Rata-rata Nilai & Kategori \\
\hline 1 & SMP N 4 & 58,18 & Developmnet \\
\hline 2 & SMP N 11 & 48,63 & Developmnet
\end{tabular}

Data pada Table 1 menunjukan rata-rata keterampilan metakognisi siswa kelas VII SMP Negeri 4 Kota Ternate sebesar 57,18 dengan kategori Developmnet, sedangkan rata-rata nilai keterampilan metakognisi SMP Negeri 11 pulau Ternate sebesar 48,63 dengan kategori Developmnet.

Untuk memperjelas perbandingan rata-rata keterampilan metakognisi siswa antara kedua sekolah dapat dijelaskan dalam grafik dibawah ini 


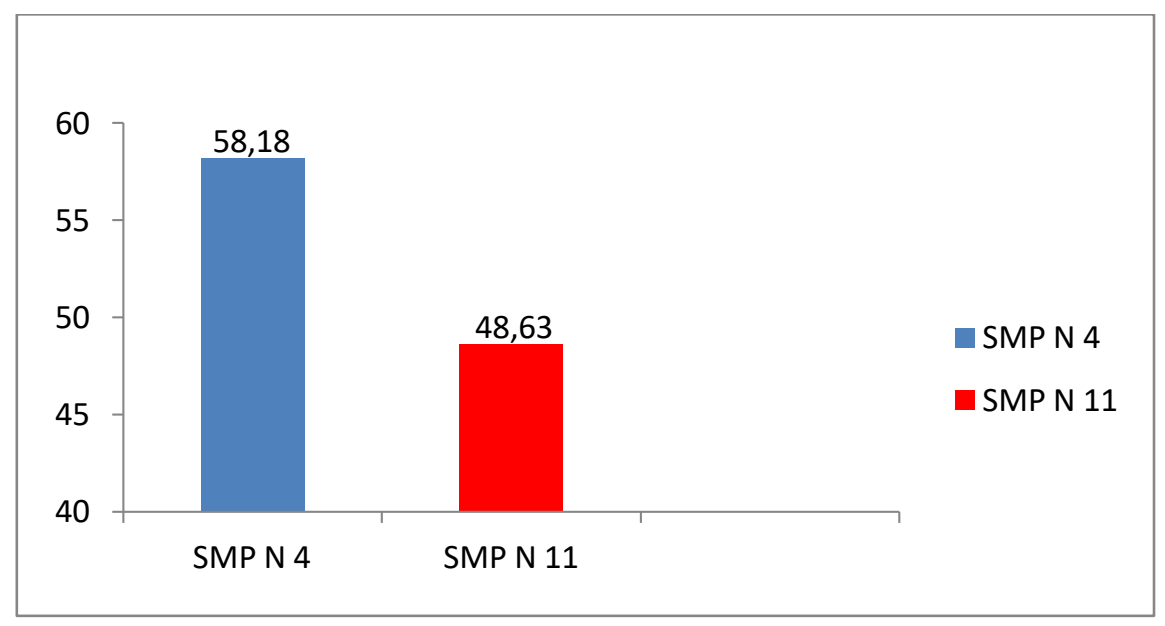

Gambar 1. Rata-Rata Keterampilan Metakognisi

Gambar 1 Menjelaskan tentang perbandingan rata-rata keterampilan metakognisi antara siswa SMP N 4 dan SMP N 11 Ternate. Adapun selisi nilai keterampilan metakognisi siswa pada kedua sekolah yaitu sebesar 8,55 artinya ada perbedaan keterampilan metakognisi pada kedua sekolah.

Hasil penelitian ini dapat dikatakan bahwa keterampilan metakognisi siswa pada kedua sekolah meiliki perbedaan pada nilai rata-rata, akan tetapi kedua sekolah ini masih masuk pada kategori Developmnet, ini berarti bahwa guru belum memberdayakan keterampilan metakognisi siswa dengan baik. Hal ini sejalan dengan pendapat (Chun-Yi and Hsiu-Chuan, 2011; Bahri and Corebima, 2015) keterampilan metakognisi belum diberdayakan oleh guru, diantaranya kemampuan siswa dalam mengelola sendiri aktivitas (Self asessment) dan kemampuan siswa dalam mengelola sendiri pengetahuan (Self management) serta kemampuanya dalam belajar.

Rendahnya keterampilan metakognisi karena pendektan pembelajaran yang dipakai guru masih bersifat konvensional. Vandalita, (2014) mengungkapkan bahwa sampai saat ini pembelajaran konvensional masih menjadi strategi yang pada umumnya diterapkan dalam pembelajaran karena dianggap dapat menjadi pilihan untuk sebuah penerapan pembelajaran yang membutuhkan waktu yang relatif singkat, cakupan materi yang diajarkan lebih luas serta dapat membekali siswa dengan pemahaman konsep. Namun, yang terjadi justru sangat bertolak belakang dengan yang diharapkan, pembelajaran konvensional justru merupakan salah satu penyebab utama rendahnya keterampilan metakognisi siswa.

\section{KESIMPULAN}

Berdasrkan hasil penelitian dapat diperoleh nilai rata-rata keterampilan metakognisi pada mata pelajaran IPA biologi siswa kelas VII SMP Negeri 4 Kota Ternate sebesar 58,18 dan SMP Negeri 11 pulau Ternate sebesar 48,63 dengan selisih perolehan 8,55 namun kedua sekolah masuk pada kategori Development, dapat dikatakan bahwa keterampilan metakognisi siswa masih rendah. Renadahnya keterampilan metakognisi siswa diduga karena guru belum memberdayakan keterampilan metakognisi dengan baik. Pendekatan pembelajaran yang digunakan guru masih bersifat konvensional. 


\section{DAFTAR PUSTAKA}

Bahri, A., Corebima, A.D., 2015. The Contribution Of Learning Motivation And Metacognitive Skill On Cognitive Learning Outcome Of Students Within Different Learning Strategies. J. Balt. Sci. Educ. 14.

Chun-Yi, S., Hsiu-Chuan, L.I.U., 2011. Metacognitive skills development: A webbased approach in higher education. TOJET Turk. Online J. Educ. Technol. 10.

Corebima, A.D. 2010. Metacognitive Measuretment Integred In Achievement Test. State Universitiy of Malang.

Corebima, AD. 2009. Metacognitive Skills Measurement Integreted in Achievement Test. Maklah disajikan dalam Third International Confrence on Science and Mathematics Education (CosMed). Malaysia, 10-12 November.

Depdiknas,2006. Kurikuluum Tingkat Satuan Pendidikan. Permendiknas 2006. Jakarta: Depdiknas.

Green, N.2002. Better Thinking Learning an Introduction to Cognitive Education, Western Cape Education Dept., (Online), http://www.curiculum.pgwe/gov.za/currdev/curhome/betterthink/idek.htm), diakses 27 maret 2017.

Hacker, D.J. Kenner M.C,\&Kricher J.C. 2009. Writing is Applied Metacognition. Dalam Hacker D.J, Dunlosky J. Graesser A.C. (Ed), Hanbook of Metakognition in Education. New York:Routledge.

Petters, E. 2006. Does Contructivist Epitomology Have a Place in Education. Journal of Nursing Education. 39 (4):166-170.

Skhoenfeld, A.H. 1992. Learning to Think Mathematically: Problem Solving, Metacogniyion, \& Sensse-Making In Mathematics. Handbook for Research on Mathematics Teaching and Learning. In D. Grouws (Ed). New York:MacMillan.

Vandalita. 2014. Pengaruh Strategi Pembelajaran Berpola PBMP dan TPS terhadap Sikap Sosial dan Retensi Siswa.

@ 2021 JPPI (https://bimaberilmu.com/jurnal/index.php/jppi) 